\title{
ERYTHROCYTE OXIDATIVE STATUS AFTER MAXIMAL AEROBIC TEST IN WRESTLERS
}

\author{
A. Alexandrova, ${ }^{1,2}$, a_alexandrova_bas@yahoo.com, ORCID: 0000-0002-7007-3665, \\ L. Petrov', dr.lubomir.petrov @gmail.com, ORCID: 0000-0003-1209-959X, \\ R. Makaveev', racho74@abv.bg, ORCID: 0000-0002-7670-9222, \\ E. Tsvetanova2, elina_nesta@abv.bg, ORCID: 0000-0002-5916-5200, \\ A. Georgieva2, almirageorgieva@gmail.com, ORCID: 0000-0003-1323-2348, \\ S. Kolimechkov ${ }^{1}$, dr.stefan.kolimechkov@gmail.com, ORCID: 0000-0003-0112-2387 \\ ${ }^{1}$ National Sports Academy, Sofia, Bulgaria, \\ ${ }^{2}$ Bulgarian Academy of Sciences, Sofia, Bulgaria
}

\begin{abstract}
Aim. The aim of this study was to determine the changes in the erythrocyte oxidative status of the wrestlers after performing the maximal aerobic test, by registering in erythrocytes the levels of lipid peroxidation (LPO), total glutathione ( $\mathrm{tGSH}$ ) and activities of catalase (CAT), superoxide dismutase (SOD), and glutathione peroxidase (GPx). Materials and methods. A group of 12 healthy wrestlers conducted a treadmill maximal aerobic test, and venous blood samples were obtained before and immediately after the exercise. Erythrocytes were separated from plasma and used for spectrophotometric determination of LPO, tGSH and enzyme activities. Plasma was used for determination of hemoglobin concentration $(\mathrm{Hb})$ as an index of hemolysis. Results. The performance of the maximal aerobic test resulted in a significant increase of $\mathrm{Hb}$ in blood plasma, a decrease of LPO, and no changes of the tGSH level in erythrocytes. In regards to antioxidant enzymes, our results showed an increase in the activity of GPX, while the CAT and SOD activity remain unchanged. Conclusions. It can be concluded that in active athletes, predominate erythrocytes that are more resistant to oxidative stress, because of the accelerated hemolysis induced by physical exercise, lead to the elimination of the old and oxidative modified cells.
\end{abstract}

Keywords: erythrocytes, maximal aerobic exercise test, oxidative status, wrestlers.

Introduction. Physical exercise leads to changes in the oxidative status of the organism. In humans, the parameters of oxidative status are most commonly studied in the blood plasma and erythrocytes.

The main function of erythrocytes is to supply cells with oxygen in order to maintain the aerobic metabolism. In this role, they are in constant contact with oxygen and are exposed to reactive oxygen species (ROS) impact. The main source of ROS in red blood cells is the autooxidation of oxyhemoglobin to methemoglobin $[14,18,20]$. During the auto-oxidation of methemoglobin, superoxide anion radicals $\left(\mathrm{O}_{2}^{-}\right)$are produced with a subsequent formation of hydrogen peroxide. The reduction of oxygen to superoxide and nitrite to nitrous oxide starts the cascades of oxidation reactions that induce oxidative stress (OS) in erythrocytes and lead to their damage [14]. All biomolecules - lipids, proteins and nucleic acids - can be a target of free radicals. The most commonly used marker for OS is the membrane lipid peroxidation (LPO), as phospholipids are the most susceptible to the action of ROS by the presence of polyunsaturated fatty acids in their structure. The erythrocytes can be attacked by ROS, generated in the blood plasma, such as hydrogen peroxide and nitric oxide. The red blood cells (RBC) are broadly investigated as a source of ROS, as well as a target for their action. To a large extent, this is determined by the wide variety of factors that can lead to hemolysis and cause hemolytic anemia [20]. It is known that the rate of auto-oxidation increases with a decrease in $\mathrm{pH}$ and $\mathrm{PO}_{2}$ (that is often observed during physical exercises) $[2,4,14]$.

To deal with the ROS and to prevent their damaging effect, RBC are equipped with a wellorganized defense system. In humans, the activity of antioxidant enzymes in the RBC is higher than in most other tissues in the body [17]. In addition to the enzymes, nonenzyme antioxidants, such as tocopherols, ascorbate, urate and glutathione, also act upon the RBC.

The purpose of this study was to determine the changes in oxidative status of erythrocytes in wrestlers, after performing the maximal aerobic test to exhaustion, by measuring the total glutathione (tGSH), the levels of thiobarbituric acid reactive substances (TBARS) as a marker of lipid 


\section{Физиология}

peroxidation (LPO), and activity of antioxidant enzymes: catalase (CAT), superoxide dismutase (SOD), and glutathione peroxidase (GPx). The maximal aerobic test was chosen because it is widely used in sports practice for tracking the working capacity of the athletes and their training level. Due to the adequate evaluation of the functional capacity of the subjects tested, and the good reproducibility of the results, it is accepted as the "gold standard". Therefore, the maximal aerobic test to exhaustion can be used as a standard workload to investigate the oxidative stress in athletes.

Methods. The study was performed in accordance with the Declaration of Helsinki for Human Research [21], and approval was obtained from the Ethics Committee of the Institute of Neurobiology, Bulgarian Academy of Sciences (registration FWA 00003059 of the US Department of Health and Human Services).

Participants. Twelve international level wrestlers ( 9 males and 3 females) took part in the study after signing an informed consent form. They completed a maximal aerobic test on a treadmill. Before the test all athletes underwent a medical examination. None of them were excluded because of irregularities in ECG and blood pressure, a history of chronic diseases, current infections, use of antibiotics and herbal, antioxidant or steroids.

Venous blood was taken (Vacuette/Li Hep) before and immediately after the maximal test.

Physical characteristics. Body weight (BW) was measured to within an accuracy of $0.05 \mathrm{~kg}$. Body height $(\mathrm{BH})$ was measured to the nearest $0.5 \mathrm{~cm}$ using a stadiometer. Body mass index (BMI) was calculated as $\mathrm{BW}(\mathrm{kg})$ divided by $\mathrm{BH}$ (m) squared. Body composition was evaluated using the bioelectrical impedance method (Tanita 418, Japan).

Maximum oxygen uptake. The maximum oxygen uptake $\left(\mathrm{VO}_{2} \mathrm{max}\right)$ was assessed by a maximal aerobic test on a treadmill $(\mathrm{H} / \mathrm{P} / \mathrm{Cosmos}$, Germany) according to the following protocol: the duration of the step was $1 \mathrm{~min} 30 \mathrm{sec}$, the initial speed was $6 \mathrm{~km} / \mathrm{h}$, and after completing each step the speed was increased by $1.2 \mathrm{~km} / \mathrm{h}$, and the slope was constant at $2.5 \%$. The analysis of exhaled gases $\left(\mathrm{O}_{2}\right.$ and $\left.\mathrm{CO}_{2}\right)$ was performed in real time, using a metabolic device (Jaeger-Pro, Germany).

Biochemical analysis. The reagents used in the present work were obtained from SigmaAldrich (Germany).

Analytical procedures. The blood was centri- fuged at $600 \mathrm{~g}$ for $10 \mathrm{~min}$ and the plasma was removed from the packed RBC. The amount of hemoglobin $(\mathrm{g} / \mathrm{L})$ in whole blood, in packed $\mathrm{RBC}$, and in plasma was determined spectrophotometrically according to a calibration curve by using Drabkin's Reagent. The packed RBC were washed twice with physiological saline and a $5 \%$ suspension (diluted according to $\mathrm{Hb}$ in $0.15 \mathrm{M}$ $\mathrm{NaCl}-10 \mathrm{mM}$ sodium phosphate buffer, $\mathrm{pH} 7.2$ ) was prepared. The RBC suspension was frozen, and the hemolysate obtained after defrosting was used for measurement of the level of LPO, tGSH and the activity of CAT, SOD, and GPx. Each sample was analyzed in triplicate. The single results obtained were in a good agreement and the mean value was taken as the final result.

The lipid peroxidation of hemolysate was estimated by the amount of thiobarbituric acid reactive substances (TBARS) [8] without LPO inductors (spontaneous LPO) and with $10 \mathrm{mM} \mathrm{H}_{2} \mathrm{O}_{2}$ and $2 \mathrm{mM} \mathrm{NaN}_{3}$ (induced LPO). The extinction at $532 \mathrm{~nm}$ was measured, and the amount of TBARS was calculated using a molar extinction coefficient of $1.56 \times 10^{5} \mathrm{M}^{-1} \mathrm{~cm}^{-1}$, and was expressed as ng malondialdehyde (MDA) per $\mathrm{mg} \mathrm{Hb}$.

Total glutathione (tGSH) level was measured according to Tietze [19]. The values were expressed in $\mathrm{ng} / \mathrm{mg} \mathrm{Hb}$, with oxidized glutathione (GSSG) as a reference standard.

Superoxide dismutase (SOD) activity was determined according to Beauchamp and Fridovich [3] and was expressed as $\mathrm{U} / \mathrm{mg} \mathrm{Hb}$. A unit of SOD activity is the amount of the enzyme producing $50 \%$ inhibition of nitroblue tetrazolium (NBT) reduction.

Catalase (CAT) activity was determined according to Aebi [1] and was expressed as $\mathrm{dA}_{240} / \mathrm{min} / \mathrm{mg} \mathrm{Hb}$.

Glutathione peroxidase (GPx) activity was determined according to Gunzler et al. [9] and was expressed in $\mathrm{U} / \mathrm{mg} \mathrm{Hb}$, using a molar extinction coefficient of $6.22 \times 10^{6} \mathrm{M}^{-1} \mathrm{~cm}^{-1}$.

Statistical analysis. The results were expressed as mean \pm SD. Statistical analyzes were performed using SPSS statistical software (SPSS for Windows, version 16.0, 2008, SPSS Inc., Chicago, USA). The statistical significance of the differences between mean values was evaluated by t-test for paired data. Statistically significant differences between the average results were evaluated at $\mathrm{p}<0.05$.

Results. The anthropometric data, along with the results of the maximal aerobic test, are presented in Table 1. The wrestlers represented different weight categories and, therefore, large 
variations in height and weight were observed. The BMI for female wrestlers was within the norm, and that for male wrestlers was slightly above $25.0 \mathrm{~kg} / \mathrm{m}^{2}\left(26.5 \pm 2.24 \mathrm{~kg} / \mathrm{m}^{2}\right)$, which is to be expected in strength sports athletes, due to the latter's greater muscle mass. All athletes were well hydrated and had a normal average percentage of body fat (at 75 percentile) according to the American College of Sports Medicine [13]. The wrestlers showed a good aerobic capacity for men $\left(\mathrm{VO}_{2} \max =52.9 \pm 3.80 \mathrm{~mL} / \mathrm{min} / \mathrm{kg}\right)$ and for women $\left(\mathrm{VO}_{2} \max =46.8 \pm 0.95 \mathrm{~mL} / \mathrm{min} / \mathrm{kg}\right)$.

Table 1

Anthropometric data and results of the maximal aerobic test of the wrestlers

\begin{tabular}{|l|c|c|}
\hline & Female & Male \\
\hline Age (years) & $21.0 \pm 1.00$ & $21.0 \pm 0.87$ \\
\hline Weight $(\mathrm{kg})$ & $58.4 \pm 3.05$ & $79.2 \pm 7.15$ \\
\hline Height $(\mathrm{cm})$ & $159.6 \pm 5.59$ & $172.9 \pm 4.25$ \\
\hline BMI $\left(\mathrm{kg} / \mathrm{m}^{2}\right)$ & $22.9 \pm 0.90$ & $26.5 \pm 2.24$ \\
\hline Water $(\%)$ & $60.3 \pm 1.53$ & $64.3 \pm 2.96$ \\
\hline Fat $(\%)$ & $17.5 \pm 1.91$ & $11.4 \pm 3.01$ \\
\hline $\begin{array}{l}\text { Test total time } \\
(\mathrm{mm}: \mathrm{ss})\end{array}$ & $10: 24 \pm 00: 32$ & $12: 42 \pm 01: 10$ \\
\hline $\begin{array}{l}\text { Maximal speed } \\
(\mathrm{km} / \mathrm{h})\end{array}$ & $13.6 \pm 0.69$ & $15.2 \pm 0.85$ \\
\hline $\begin{array}{l}\text { VO } \\
(\mathrm{mL} / \mathrm{min} / \mathrm{kg})\end{array}$ & $46.8 \pm 0.95$ & $52.9 \pm 3.80$ \\
\hline HRmax $(\mathrm{bpm})$ & $193.0 \pm 3.00$ & $190.3 \pm 3.10$ \\
\hline
\end{tabular}

The blood hemoglobin before the test was near to the lower normal limits for females $(119.70 \pm 7.16 \mathrm{~g} / \mathrm{L})$ and for males $(140.79 \pm$ $\pm 19.17 \mathrm{~g} / \mathrm{L})$. After the test, the blood hemoglobin increased insignificantly. After completion of the maximal aerobic test, the hemoglobin concentration in the blood plasma increased significantly $(\mathrm{p}<0.01)$ (Table 2$)$.

The results of the erythrocytes' oxidative status are presented in Table 3 . There were no significant differences between the values obtained for males and females, and, therefore, the data are presented for both sexes together. The results showed a significant decrease in both spontaneous and induced LPO level immediately after completion of the maximal aerobic test. The levels of tGSH didn't change significantly. The individual baseline values for tGSH in the athletes tested showed large variations (minimum $1401 \mathrm{ng} / \mathrm{mg} \mathrm{Hb}$ and maximum $3122 \mathrm{ng} / \mathrm{mg} \mathrm{Hb}$ ), which along with the relatively small number of participants could be the reason for the lack of significance in the results. The activity of SOD before and immediately after the maximal aerobic test showed no significant changes; however, great differences in individual enzyme activity between athletes before the test ( $\min 6.40 \mathrm{U} / \mathrm{mg} \mathrm{Hb}$, $\max 18.17 \mathrm{U} / \mathrm{mg} \mathrm{Hb}$ ) were detected. The results showed a statistically significant increase of GPx after the maximal aerobic test.

Table 2

Hematological data before and after the maximal aerobic test

\begin{tabular}{|l|c|c|}
\hline Blood hemoglobin $(\mathrm{g} / \mathrm{L})$ & Before & After \\
\hline Female & $119.70 \pm 7.16$ & $121.68 \pm 7.32$ \\
\hline Male & $140.79 \pm 19.17$ & $154.41 \pm 26.55$ \\
\hline Hemoglobin in plasma $(\mathrm{g} / \mathrm{L})$ & Before & After \\
\hline Female & $0.71 \pm 0.12$ & $1.37 \pm 0.50^{*}$ \\
\hline Male & $1.56 \pm 1.35$ & $3.05 \pm 1.79^{*}$ \\
\hline
\end{tabular}

Here and in table $3 *-\mathrm{p}<0.01$.

Table 3

Erythrocyte oxidative status before and after the maximal aerobic test

\begin{tabular}{|l|c|c|}
\hline & Before & After \\
\hline LPO spontaneous $(\mu \mathrm{mol} / \mathrm{gHb})$ & $5.43 \pm 0.57$ & $4.06 \pm 0.30^{*}$ \\
\hline LPO induced $(\mu \mathrm{mol} / \mathrm{gHb})$ & $30.95 \pm 3.34$ & $22.25 \pm 1.84^{*}$ \\
\hline tGSH $(\mathrm{ng} / \mathrm{mg} \mathrm{Hb})$ & $2159.9 \pm 168.17$ & $2089.30 \pm 170.22$ \\
\hline SOD $(\mathrm{U} / \mathrm{mg} \mathrm{Hb})$ & $13.25 \pm 0.97$ & $13.78 \pm 1.37$ \\
\hline CAT $(\mathrm{U} / \mathrm{mg} \mathrm{Hb})$ & $2158.88 \pm 78.04$ & $1912.08 \pm 80.69$ \\
\hline GPx $(\mathrm{U} / \mathrm{mg} \mathrm{Hb})$ & $9.00 \pm 0.35$ & $10.03 \pm 0.49^{*}$ \\
\hline
\end{tabular}




\section{Физиология}

Discussion. Our results indicated a significant increase of the amount of $\mathrm{Hb}$ in blood plasma immediately after the test. The established two-fold increase in the plasma $\mathrm{Hb}$ could be explained by intravascular hemolysis, occurring during the maximal aerobic test. Such hemolysis in athletes was documented during long aerobic physical exercises with submaximal intensity [15]. This hemolysis leads to increased erythrocyte turnover [16], and this is, moreover, considered by some authors to be one of the causes of anemia in athletes $[15,16]$. Hemolysis may be caused by several factors, such as sheer stress, temperature, osmotic and $\mathrm{pH}$ changes [10]. An important factor of RBC hemolysis is the OS caused by a deficiency in their antioxidant system and/or by increased generation of free radicals [12].

In our opinion, reduced levels of spontaneous LPO are due to the fact that older erythrocytes, with more oxygenated membranes, have undergone hemolysis during exercise. Thus, younger erythrocytes with less membrane initial lipid peroxidation and higher hemolytic resistance remain in the blood.

The reduced induced LPO can also be explained by the fact that hemolysis-free erythrocytes have increased antioxidant protection. This specific claim is also supported by the higher GPx activity in erythrocytes after the performance of the maximal aerobic test, as established in this study. This may be also due to the induction of the GPx from the LPO production during exercise [22]. For instance, the performance of a graded exercise on a cycle ergometer till exhaustion by elite wrestlers led to a significant increase of SOD and CAT in erythrocytes [11]. However, the data of our study do not show significant changes in these enzymes.

Some authors [5] reported a decrease in the levels of erythrocytes LPO in people involved in active sports. This observation seems paradoxical because of elevated OS during regular physical exertion. However, in active athletes, the erythrocyte turnover is accelerated, and enhanced degradation of old and oxidative modified erythrocytes was registered. As a result, in the athletes' blood, the RBC that are more resistant to oxidative stress predominate.

In addition, the endurance training may modify the resting activity of antioxidant enzymes in erythrocytes. In general, higher activities of antioxidant enzymes were established in the erythro- cytes of athletes compared to those in people who are not actively engaged in sports [6].

It has been suggested that the degree of oxidative stress, induced by aerobic exercise, could be time-dependent. According to FisherWellman \& Bloomer [7], the submaximal and maximal aerobic loads must be of at least 30 minutes to cause significant ROS-mediated damage. It is possible that with longer duration loads (in our study, it is only 10-12 minutes on average), oxidative changes could also be observed in the membranes of erythrocytes that have not undergone hemolysis.

Conclusions. The performance of the maximal aerobic test with a duration of about $12 \mathrm{~min}$ (as in this study) is sufficient for induction of oxidative stress and hemolysis only in older and less resistant erythrocytes. Thus, erythrocytes with no LPO damages and with higher antioxidant defense remain in the blood.

The accelerated turnover of the erythrocytes, induced by the exercise, possibly contributes to a decrease in the levels of LPO in the erythrocytes. In addition, higher activities of erythrocyte antioxidant enzymes established in people actively involved in sports, is possibly due to the fact that the erythrocytes with weak antioxidant enzymes activity are regularly eliminated during exercises.

Acknowledgements. This work was supported by Grant ЦРАC2/22.03.2016 from the National Sports Academy, Sofia, Bulgaria.

\section{References}

1. Aebi H. Catalase in Vitro. Methods in Enzymology, 1984, vol. 105, pp. 121-126. DOI: 10.1016/S0076-6879(84)05016-3

2. Alexandrova A., Eroglu Y., Petrov L., Makaveev R., Georgieva A., Tzvetanova E. Blood Plasma Oxidative Stress Parameters after Maximal Oxygen Consumption Test in Wrestlers. International Journal of Sport Studies, 2016, vol. 6, pp. 359-366.

3. Beauchamp C., Fridovich I. Superoxide Dismutase: Improved Assays and an Assay Applicable to Acrylamide Gels. Anal Biochem, 1971, vol. 44, pp. 276-287. DOI: 10.1016/00032697(71)90370-8

4. Bogdanska J.J., Korneti P., Todorova B. Erythrocyte Superoxide Dismutase, Glutathione Peroxidase and Catalase Activities in Healthy Male Subjects in Republic of Macedonia. 
Bratislavské Lekárske Listy, 2003, vol. 104, pp. 108-114.

5. Dane S., Taysi S., Gul M., Akcay F., Gunal A. Acute Exercise Induced Oxidative Stress is Prevented in Erythrocytes of Male Long Distance Athletes. Biology of Sport, 2008, vol. 25, pp. 115-124.

6. Djordjevic D., Cubrilo D., Macura M., Barudzic N., Djuric D., Jakovljevic V. The Influence of Training Status on Oxidative Stress in Young Male Handball Players. Molecular and Cellular Biochemistry, 2011, vol. 351, pp. 251-259. DOI: 10.1007/s11010-011-0732-6

7. Fisher-Wellman K., Bloomer R.J. Acute Exercise and Oxidative Stress: a 30 Year History. Dynamic Medicine: $D M, 2009$, vol. 8, p. 1 .

8. Gilbert H.S., Stump D.D., Roth E.F. A Method to Correct for Errors Caused by Generation of Interfering Compounds During Erythrocyte Lipid Peroxidation. Analytical Biochemistry, 1984, vol. 137, pp. 282-286. DOI: 10.1016/0003-2697(84)90086-1

9. Günzler W.A., Vergin H., Müller I., Flohé L. Glutathione Peroxidase VI: the Reaction of Glutahione Peroxidase with Various Hydroperoxides. Hoppe-Seyler's Zeitschrift für Physiologische Chemie, 1972, vol. 353, pp. 1001-1004.

10. Hanzawa K., Kai M., Hiraga A., Watanabe S. Fragility of Red Cells During Exercise is Affected by Blood $\mathrm{pH}$ and Temperature. Equine Veterinary Journal, 1999, suppl. 610-1.

11. Hubner-Wozniak E., Panczenko-Kresowska B., Starczewska-Czapowska J. The Effect of Graded Exercise on Changes in the Activity of Antioxidant Enzymes in Blood of Wrestlers. BiolSport, 1993, vol. 10, pp. 21-22.

12. Iuchi Y. (2012) Anemia Caused by Oxidative Stress. In: Silverberg DS (ed) Anemia. 2012. 480 p. DOI: $10.5772 / 31404$

13. Kaminsky L.A., American College of Sports Medicine., American College of Sports Medicine. ACSM's Health-Related Physical Fitness Assessment Manual. Wolters Kluwer Health/Lippincott Williams \& Wilkins. 2014.

14. Rifkind J.M., Nagababu E., Ramasamy S., Ravi L.B. Hemoglobin Redox Reactions and Oxidative Stress. Redox Report: Communica- tions in Free Radical Research, 2003, vol. 8, pp. 234-237. DOI: 10.1179/135100003225002817

15. Selby G.B., Eichner E.R. Endurance Swimming, Intravascular Hemolysis, Anemia, and Iron Depletion. New Perspective on Athlete's Anemia. The American Journal of Medicine, 1986, vol. 81, pp. 791-794. DOI: 10.1016/00029343(86)90347-5

16. Smith J.A., Kolbuch-Braddon M., Gillam I., Telford R.D., Weidemann M.J. Changes in the Susceptibility of Red Blood Cells to Oxidative and Osmotic Stress Following Submaximal Exercise. European Journal of Applied Physiology and Occupational Physiology, 1995, vol. 70, pp. 427-436. DOI: 10.1007/BF00618494

17. Spasic M.B. Antioxidative Defence in Mammals - A Review. Jugoslov Med Biohem, 1993, vol. 12, pp. 1-9.

18. Tauler P., Aguiló A., Guix F., Jiménez F., Villa G., Tur J., Córdova A., Pons A. PreExercise Antioxidant Enzyme Activities Determine the Antioxidant Enzyme Erythrocyte Response to Exercise. J Sports Science, 2005, vol. 23, pp. 5-13. DOI: 10.1080/02640410410001716724

19. Tietze F. Enzymic Method for Quantitative Determination of Nanogram Amounts of Total and Oxidized Glutathione: Applications to Mammalian Blood and Other Tissues. Analytical Biochemistry, 1969, vol. 27, pp. 502-522. DOI: 10.1016/0003-2697(69)90064-5

20. Winterbourn C.C. Haemoglobin Oxidation and Free Radical Production in the Red Cell. Biomedica Biochimica Acta, 1983, vol. 42, pp. 134-138.

21. WMA. WMA Declaration of Helsinki Ethical Principles for Medical Research Involving Human Subjects. 2013. Available at: http://www.wma.net/en/30publications/10policie s/b3/. Accessed 27.07.2016.

22. Zavodnik L.B., Zavodnik I.B., Niekurzak A., Szosland K., Bryszewska M. Activation of Red Blood Cell Glutathione Peroxidase and Morphological Transformation of Erythrocytes Under the Action of Tert-Butyl Hydroperoxide. Biochemistry and Molecular Biology International, 1998, vol. 44, pp.577-588. DOI: $10.1080 / 15216549800201612$

Received 17 December 2018 


\title{
ОКСИДАТИВНЫЙ СТАТУС ЭРИТРОЦИТОВ ПОСЛЕ МАКСИМАЛЬНОГО АЭРОБНОГО ТЕСТА У БОРЦОВ
}

\author{
А. Александрова ${ }^{1,2}$, Л. Петров ${ }^{1}$, Р. Макавеев ${ }^{1}$, \\ Э. Цветанова ${ }^{2}$, А. Георгиева ${ }^{2}$, С. Колимечков \\ ${ }^{1}$ Национальная Спортивная Академия, г. Софрия, Болгария, \\ ${ }^{2}$ Болгарская Академия Наук, г. София, Болгария
}

Цель. Данное исследование проводилось с целью выявления изменений в оксидативном статусе эритроцитов у борцов после выполнения максимального аэробного теста. В рамках исследования проводилась регистрация уровня пероксидации липидов, общего глутатиона, активности каталазы, супероксиддисмутазы и глутатионпероксидазы. Материалы и методы. 12 здоровых борцов приняли участие в максимальном аэробном тесте на беговой дорожке. Перед тестированием и сразу после выполнения упражнения у участников были взяты образцы венозной крови. Из плазмы крови были выделены эритроциты, в которых методом спектрофотометрии были исследованы пероксидация липидов, общий глутатион и активность ферментов. Плазма была также использована для определения концентрации гемоглобина как показателя гемолиза. Результаты. Выполнение максимального аэробного теста спровоцировало значительное повышения уровня гемоглобина в плазме крови и снижение пероксидации липидов, однако никак не повлияло на уровень общего глутатиона в эритроцитах. Что касается антиоксидантных ферментов, то результаты анализа показали увеличение активности глутатионпероксидазы, при этом активность каталазы и супероксиддисмутазы осталась на том же уровне. Заключение. Можно прийти к выводу, что у активных спортсменов преобладают эритроциты, которые более устойчивы к оксидативному стрессу вследствие ускоренного гемолиза, спровоцированного физическими упражнениями, которые приводят к удалению старых и оксидативно модифицированных клеток.

Ключевые слова: эритроциты, максимальный аэробный тест, оксидативный стаmyc, борицы.

Александрова Альбена, PhD, доцент кафедры физиологии и биохимии, Национальная спортивная академия; лаборатория свободнорадикальных процессов, Институт нейробиологии, Болгарская академия наук. Болгария, г. София, 1113, ул. Академика Бончева, 23. E-mail: a_alexandrova_bas@yahoo.com, ORCID: 0000-0002-7007-3665.

Петров Любомир, $\mathrm{PhD}$, доцент кафедры физиологии и биохимии, Национальная спортивная академия. Болгария, г. София, 1700, ул. Академик Стефан Младенов, 21. E-mail: dr.lubomir.petrov (a)gmail.com, ORCID: 0000-0003-1209-959X.

Макавеев Рашо, PhD, доцент кафедры реслинга и дзюдо, тренерский факультет, Национальная спортивная академия. Болгария, г. София, 1700, ул. Академик Стефан Младенов, 21. E-mail: racho74@abv.bg, ORCID: 0000-0002-7670-9222.

Цветанова Элина, PhD, лаборант лаборатории свободнорадикальных процессов, Институт нейробиологии, Болгарская академия наук. Болгария, г. София, 1113, ул. Академика Бончева, 23. E-mail: elina_nesta@abv.bg, ORCID: 0000-0002-5916-5200. 
Георгиева Альмира, лаборант лаборатории свободнорадикальных процессов, Институт нейробиологии, Болгарская академия наук. Болгария, г. София, 1113, ул. Академика Бончева, 23. E-mail: almirageorgieva@gmail.com, ORCID: 0000-0003-1323-2348.

Колимечков Стефан, $\mathrm{PhD}$, научный сотрудник кафедры физиологии и биохимии, Национальная спортивная академия. Болгария, г. София, 1700, ул. Академик Стефан Младенов, 21. E-mail: dr.stefan.kolimechkov@gmail.com, ORCID: 0000-0003-0112-2387.

Поступила в редакцию 17 декабря 2018 г.

\section{ОБРАЗЕЦ ЦИТИРОВАНИЯ}

Erythrocyte oxidative status after maximal aerobic test in wrestlers / A. Alexandrova, L. Petrov, R. Makaveev et al. // Человек. Спорт. Медицина. - 2019. T. 19, № 1. - C. 15-21. DOI: 10.14529/hsm190102

\section{FOR CITATION}

Alexandrova A., Petrov L., Makaveev R., Tsvetanova E., Georgieva A., Kolimechkov S. Erythrocyte Oxidative Status after Maximal Aerobic Test in Wrestlers. Human. Sport. Medicine, 2019, vol. 19, no. 1, pp. 15-21. DOI: $10.14529 / \mathrm{hsm} 190102$ 